\title{
Surveillance Technologies and States of Security
}

\section{I BUNKER MENTALITY}

Mexico's Federal Police Intelligence Center (CIPF) was inaugurated on November 24, 2009, in a ceremony attended by President Felipe Calderón and Secretary of Public Security Genaro García Luna. The CIPF, a subterranean structure colloquially known as El Bunker, serves as the command center for the federal government's War on Crime. ${ }^{a}$ It houses Plataforma México, a network of advanced telecommunication and information technologies receiving data from over six hundred state and municipal offices; 169 federal police stations; the national registries of people, vehicles, criminal records, fingerprints, and ballistics; and video cameras located throughout the country, including those at the Basilica of Our Lady of Guadalupe, dedicated to the Virgin of Guadalupe, the patron saint of Mexico. ${ }^{\mathrm{I}}$ To visualize the data, El Bunker features four video walls, each measuring 65 by ro feet, displaying eighty rear-screen projectors arranged in four 2 by ro configurations. ${ }^{2}$ In his remarks, President Calderón claimed that the center would serve as a

a. The federal government's security campaign has carried various monikers-la Guerra contra el Narco (the War against the Narcos), la Lucha contra la Inseguridad (the Fight against Insecurity), la Guerra contra el Crimen (the War against Crime or the War on Crime), among others. Of these, the War against the Narcos and the War on Crime were the most common during the Calderón administration. I use the term "War on Crime" because it captures the fact that the government is targeting forms of illicit behavior beyond drug trafficking. 
"computer brain" to keep the federal police "a step ahead of crime." It would allow Mexico to win its War on Crime, he explained, since "wars are won with this, with technology, information, intelligence, planning, and force." With these words, the Mexican leader gave voice to his administration's faith in the power of technology to defeat crime.

Situated off the southwest corner of Chapultepec Park, Mexico City's verdant oasis, El Bunker's proximity to the park's other iconic buildings-Chapultepec Castle and Los Pinos-provides a commentary on the evolving relationship between governors and the governed in Mexico. Chapultepec Castle, located at the highest point of the park, is a regal structure that was commissioned by Viceroy Bernardo de Gálvez in 1775 and given its current appearance by the Austrian-born Emperor Maximilian I of Mexico in I 864. Behind the castle in the south-central section of the park, the more austere Los Pinos was constructed on the order of President Venustiano Carranza in I9I7 and has been the primary home for Mexico's heads of state since 1934, when President Lázaro Cárdenas moved the presidential residence out of Chapultepec Castle. El Bunker, meanwhile, with its central conference room that seats the president and his security cabinet in the event of a national emergency, is a two-story underground structure powered by an independent energy source. If Chapultepec Castle pronounced the presence of a royal authority through its privileged position above Mexico City, and if Los Pinos symbolized the progressive ideals of Mexico's postrevolutionary government to level the distance between the country's most and least powerful sectors, El Bunker embodies the security anxieties of the contemporary government, which would secure society by placing its administrative center outside the grasp of the general population while maintaining oversight through advanced surveillance technologies.

A solid five years into the intelligence center's existence, its value remains in doubt. Although homicides, robberies, and extortions are down in recent years, violent crime remains high throughout the country. ${ }^{4}$ And the government's limited capacity to combat criminal wrongdoing has been underscored by dramatic events such as the massacre of forty-three students of the Raúl Isidro Burgos Rural Teachers' College of Ayotzinapa in September 20I 4 and the escape of Joaquín "El Chapo" (Shorty) Guzmán from a maximum security prison in July 2015. These high-profile crimes, like most delinquency in Mexico, remain unsolved. As regards the center itself, it has been dogged by numerous problems, including unmanageable historical data, unreliable interagency 
communications, the reluctance of state agencies to share data, and manual processes of information keeping at the local level that slow data processing and accuracy. ${ }^{5}$ These challenges have not diminished the government's faith in technology. "It is a matter of time," officials assert, when asked about the center's impact on crime. ${ }^{6}$ And additional police bunkers have been constructed in Mexico since. ${ }^{7}$ But in Mexico's War on Crime, one wonders whether time and technology will be enough.

\section{I.2 LIVING IN THE SURVEILLANCE SOCIETY}

This is a book about surveillance technologies and their impact on the relationship between authorities and those they govern. Surveillance, defined as "any collection or processing of personal data, whether identifiable or not, for the purposes of influencing or managing those whose data have been garnered," ${ }^{8}$ has become a topic of growing popular and scholarly interest the last twenty years. This is reflected in the attention paid to it by Hollywood (in films such as The Truman Show, Gattaca, Lost Highway, Minority Report, Panic Room) and academia (in the journal Surveillance and Society, as well as a number of recent books). This growing popularity does not owe to the novelty of surveillance, since surveillance is not new. Political authorities have always kept track of people, just as parents have always looked after their children, teachers tracked their students, doctors monitored their patients, and bosses watched over their workers.

But how we watch has changed, thanks to the proliferation of computers, mobile devices, CCTV cameras, RFID chips, and other gadgets in society today. "Traditional surveillance," the seminal surveillance scholar Gary T. Marx notes, was characterized by "close observation, especially of a suspected person." "New surveillance," however, is performed "through the use of technical means to extract or create personal or group data, whether from individuals or contexts." And on a daily basis, we come into contact with a host of technologies whose surveillant capacities are transforming the contours of social life. "Helicopter parents" wield "electronic leashes" to remain ever present in the lives of their children, classrooms are turned "inside out" or made into "MOOCs" to accommodate greater numbers of students, doctors connect to patients in "eICUs," and "job spill" and "workweek creep" befall greater numbers of workers.

At the level of national security, networks of computers armed with powerful processors and sophisticated software scoop up data 
transmitted across the Internet and allow governments to track and store the content of people's digital communications. Backscatter X-ray imaging devices enable security officers at airports to effortlessly photograph travelers through their clothes. The advent of unmanned aerial vehicles (UAV) armed with missiles that can be guided by video operators has simplified the assassination of suspected terrorists overseas. Closed-circuit television (CCTV) and Internet-protocol television cameras allow dummy police officers to monitor public spaces. Biometric technologies such as fingerprinting and iris scans make possible the identification of billions of people across the globe. And tracking cars and people would be many times more difficult without the radio-frequency identification (RFID) chips or global positioning system (GPS) devices that can attach to them.

The ubiquity of surveillance technologies might make us yearn for earlier times, when our lives were not shackled by such objects. But we should resist such knee-jerk reactions. The sense that privacy is under assault today is not imagined. The unsolicited email or phone call speaks to the capacity of information systems to link diverse databases. ${ }^{\mathrm{I}}{ }^{\circ}$ The ability of online vendors such as Amazon or Netflix to predict our reading, listening, or viewing preferences evidences how those watching know more about us than we do ourselves. ${ }^{\text {II }}$ And the requirement that we possess a driver's license in order to board an airplane speaks to the propensity of technologies to not only "creep" ${ }^{\mathrm{I2}}$ but "surge" ${ }^{\mathrm{I3}}$ into applications beyond their original design. But we must weigh these concerns against considerations of how privacy and personal data are not so much invaded by surveillance technologies as willingly offered up by people as "tokens of trust" ${ }^{\text {I4 }}$ necessary for social exchanges in today's world. We share the details of our lives on Facebook or with online vendors so that we can move more freely and buy more cheaply than if constrained to our immediate community. Loss of privacy thus equates with greater freedom of movement and other privileges. In addition, technologies such as cell phones and encryption programs enhance privacy by providing greater anonymity than in the past. ${ }^{15}$ Online purchasing is more or less secure. And encryption and anonymization programs such as GnuPG and Tor have proven to be effective enough that the US government purposefully retains encrypted or anonymous data in the hopes of cracking their codes. ${ }^{16}$

Privacy concerns connect with identity as well. The digital identities that people construct on Facebook (or have constructed for them based on the digital trails they leave online) serve as "data doubles," 
“dividuals," ${ }^{18}$ or "electronic doppelgängers." ${ }^{19}$ At the same time, biometric technologies such as iris scans and genetic fingerprinting assign identity by anchoring it to one's body. ${ }^{20}$ In both instances, technologies threaten the self, ${ }^{2 I}$ as people find their ability to define who they are reduced and the line between the self and other fades. ${ }^{22}$ The ubiquity of surveillance technologies affects group identity too. CCTV cameras installed in housing developments disrupt forms of community as people cut the amount of time spent in open areas where community engagement traditionally occurs. ${ }^{23}$ That said, biometric technologies such as those utilized in India's population registry hold the possibility of guaranteeing personal identity and the civic rights and privileges that citizenship entails. ${ }^{24}$ Likewise, DNA testing has revolutionized the criminal justice system in the United States, ${ }^{25}$ helping identify scores of individuals wrongfully incarcerated for crimes they did not commit and thus bringing some measure of justice to individuals and communities wrongfully targeted by law enforcement.

DNA tests bring to mind the reliability of technical methods of seeing and their potential to predict crime ${ }^{26}$ and realize "front end control." There is evidence that the innovative use of crime statistics in programs such as COMPSTAT is effective in reducing property crime. ${ }^{28}$ And government officials cite the efficacy of surveillance in stopping terrorist attacks. ${ }^{29}$ But it is of course impossible to know that such malicious plans would not have been thwarted by more conventional law-enforcement tactics. What is more, these technologies were unable to preempt the Boston Marathon bombers, Dzhokhar and Tamerlan Tsarnaev, even though surveillance programs "discriminate by design" against foreign nationals. ${ }^{30}$ Also, with relation to ordinary street crime, organizational

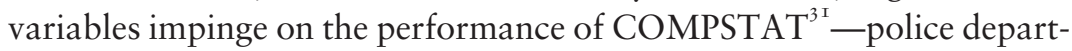
ments continue to define policing as patrol work and do not undertake the institutional reorganization called for under the program. Surveillance technologies are additionally challenged by the uncertain nature of the phenomena they look to control. The spelling of names ${ }^{32}$ and the features of faces ${ }^{33}$ change over time, and data can be coded in incompatible formats, ${ }^{34}$ duplicate places, ${ }^{35}$ or stripped of meaning in the coding process. $^{36}$

The uneven performance record of surveillance technologies in providing security might give public officials pause in adopting them. But this has clearly not been the case. ${ }^{37}$ At the time of writing, local, state, and federal law-enforcement agencies and local legislatures in the United States are exploring the adoption of UAVs or drones to fight crime ${ }^{38}$ and 
combat illegal immigration. ${ }^{39}$ This disconnect between actions and outcomes speaks to, on the one hand, the influence of "security cultures," or "prevailing understandings of threats and appropriate responses to them," on public policy in the United States. ${ }^{40}$ TV shows, movies, and news reports disproportionately focus on terrorism and glamorize the ability of sophisticated technologies and muscular men using extralegal means (James Bond, Ethan Hunt, Jack Bauer) to stop terrorism. ${ }^{4 \mathrm{I}}$ The September II, 200I, terrorist attacks in the United States also intensified existing trends of "governing through crime," use crime prevention as a rationale for expanding techniques and technologies of social control. The disconnect between the government's increasing adoption of technologies and the lack of evidence for their efficacy also speaks to, on the other hand, the influence of the private sector over public life. Private companies produce and operate many of these technologies. ${ }^{43}$ Companies lobby governments to adopt their wares $^{44}$ and advertise so that individual citizens adopt them to make themselves safe. In the United Kingdom, private CCTV operators gradually assume discretionary power from police officers in deciding whom to place under watch. ${ }^{45}$ In this sense, instead of Big Brother, it makes more sense today to speak of the increasing number of Little Brothers who exercise authority over ordinary people. ${ }^{46}$

The growing influence exercised by private actors gives the impression that fundamental processes affecting the nature of political life in our democratic societies are increasingly out of our hands. Programs of surveillance and secret prisons for terrorist suspects operate outside the US court system and beyond public oversight. ${ }^{47}$ At the theoretical level, many scholars have observed that surveillance technologies are part of an alteration in the nature of power in society underscored by "social sorting." ${ }^{48}$ At national borders, programs like US VISIT sort between safe/legitimate and dangerous/illegitimate travelers. ${ }^{49}$ On city streets, CCTV operators differentiate between desirables and undesirables, and intelligent transportation systems (ITS) implement "throughput rationality" to prioritize certain mobilities (motor vehicles) over others (pedestrians). ${ }^{50}$ In correctional facilities, good risks for rehabilitation are separated from bad risks. ${ }^{5 I}$ Slowly, political philosophies enshrining universal rights are yielding to utilitarian technocratic practices dividing us between good and bad risks.

For many, this ongoing advance of surveillance technologies engenders a breakdown in "institutional trust" and invites resistance. ${ }^{52}$ Resistance can run from the momentous to the mundane. Concerned 
individuals, such as Chelsea Manning and Edward Snowden, with knowledge of or access to secret government communications and programs have leaked information to the public. Concerned organizations, such as the Electronic Frontier Foundation (EFF) or Electronic Privacy Information Center (EPIC), have brought lawsuits against the US government and communication companies for violating privacy laws and civil liberties. ${ }^{53}$ Meanwhile, individuals confronting drug testing at work might either directly refuse to participate in testing, avoid it by hiding or not attending work, switch clean for tainted samples, distort the test by consuming substances to neutralize the evaluation, and so on. ${ }^{54}$ Those collecting welfare benefits will engage in paid labor in violation of state regulations. ${ }^{55}$ And people under the watch of CCTV monitoring take to playing for the camera ${ }^{56}$ or defy the authority of watchers by displaying a middle finger. ${ }^{57}$

\section{3 SURVEILLANCE TECHNOLOGIES IN AN INSECURE WORLD}

But how would we react to surveillance if we found ourselves elsewhere? Globally, authorities are exercising novel means for monitoring people in the name of security. France operates a massive secret telecommunications surveillance program designed to identify security threats. ${ }^{58}$ Before the United States and France, the government of Nigeria was suspected of operating a program to monitor Internet communications. ${ }^{59}$ India is creating a national registry of people based on the fingerprints and iris scans of its over one billion citizens. ${ }^{60}$ Thailand has begun installing video cameras into the life-sized, fiberglass decoy police officers that dot the country in order to combat street crime. Brazil has created an electronic vehicle registration program that will be able to track motor vehicles by attaching RFID chips to them. ${ }^{62}$ And the list goes on.

If there are now "eyes everywhere" ${ }^{63}$ and surveillance technologies are an essential aspect of globalization, this does not mean that they always see in the same way. Local, national, and regional contexts shape their distribution and intensity. ${ }^{64}$ In Rio de Janeiro, video cameras are employed by competing police forces from different levels of government and by private citizens in pursuit of security against organized crime, while in Tokyo they are embraced by civic community groups in a highly bureaucratized fashion that is indicative of a "surveillance society." Within Latin America, countries such as Brazil, Mexico, and 
Venezuela are outpacing others in their turn to surveillance technologies to ensure public security. ${ }^{6}$

The consideration of surveillance technologies in the Global South is timely. In Latin America, violence and security have become dominant themes over the last decade, following the processes of democratization from military and authoritative regimes during the 1990 o. ${ }^{67}$ While organized crime exists in the Global North, with gang violence affecting quality of life in neglected urban areas, its scale and intensity are dramatically higher in Latin America. Levels of delinquency have surged in many countries, especially Brazil, Mexico, Venezuela, and much of Central America. ${ }^{68}$ Not only have governments been unable to deal with the violence, but organized crime now comprises the sociopolitical order. ${ }^{69}$ States may use extralegal (or criminal) force against unions, gangs, or political opponents, while in other instances elements of the state may use organized crime to enrich themselves. Crime syndicates may buy off state actors in order to protect their operations, while in other instances violence is used as a means of conflict resolution where more formal legal channels are not available. ${ }^{70}$ These "violent multiplicities" ${ }^{71}$ highlight how the transition to democracy in Latin America has not brought a strong rule of law or civilian control of military forces, basic elements of democratic rule. ${ }^{72}$

Mexico is very much part of this story. The country has undergone a number of profound changes in recent decades. It experienced a progressive opening of its political system, highlighted in 2000 by the election of a president (Vicente Fox) from a party (the PAN, or National Action Party) other than the PRI (Institutional Revolutionary Party), which had dominated political life since the end of the Mexican Revolution in the late I920s. The democratization of Mexico follows two decades of economic liberalization begun by President Miguel de la Madrid in the I980s and reinforced with the North American Free Trade Agreement (NAFTA) in I994, clear moves away from the protectionist, import-substitution economic model embraced by the PRI since the Great Depression. The political and economic transformations have been accompanied by cultural changes as well, as consumerism and globalization have reshaped national identity in the world's second most populous Catholic country. While the consequences of these processes are subject to debate, Mexico's entry into the twenty-first century promised a break from its more immediate past.

The massive violence of the last decade has cast a shadow over these developments, however. Much of the insecurity is of course driven by 
illicit drug trafficking contested by organized crime syndicates. Sharing a long terrestrial border with the United States, Mexico has been the preferred point of transit for cocaine shipments from South America since increased policing of the Caribbean Sea diminished the lucrativeness of water transits. ${ }^{73}$ Since 1997, when Amado Carrillo Fuentes, leader of the Juárez cartel, died following plastic surgery intended to hide his identity, different cartels have been battling for control of the Juárez plaza (territory and supply route). This competition intensified in 2007 when Joaquín "El Chapo" (Shorty) Guzmán, leader of the Sinaloa cartel, allegedly was unable to come to an agreement with a rival cartel about access to Juárez. ${ }^{74}$ The battles between the cartels have resulted in an increasing number of drug-related murders. ${ }^{75}$

However, drugs comprise just a portion of the crime problem in Mexico. While official crime statistics are unreliable, given the large amount of unreported crime (cifra negra), kidnappings, extortions, and street robberies have been on the rise. ${ }^{76}$ Elevated crime also reflects the inefficacy of Mexican federal, state, and local governments to respond to delinquency. The country ranks high in international measures of impunity, ${ }^{77}$ with national surveys indicating that over 93 percent of all crimes are either not reported or not investigated by authorities. ${ }^{78}$ And half of the cases that are investigated do not result in further legal action. $^{79}$ As a result of insecurity and the state's inability to confront it, Mexicans report low levels of confidence in their police and public leaders. ${ }^{8 \circ}$

Upon assuming office in December 2006, President Felipe Calderón launched a War on Crime to counter this insecurity. Dropping past administrations' de facto policy of passivity and complicity toward the drug cartels, Calderón moved to disrupt their operations by reinventing public institutions and crime-fighting strategies. ${ }^{8 \mathrm{I}}$ National legislation was passed to increase punishments against criminals and to authorize the use of the military in fighting crime, ${ }^{82}$ police forces were created and reorganized to reduce corruption and increase effectiveness, ${ }^{8_{3}}$ international agreements were struck with neighboring countries to coordinate anticrime strategies, ${ }^{84}$ national agreements were reached with the country's media to manage the content and tone of news reports, ${ }^{85}$ and public relations campaigns were launched to increase public confidence and participation in crime reporting. ${ }^{86}$

Surveillance technologies have figured centrally in Mexico's crime fight. The Mérida Initiative signed by President Calderón and US president George W. Bush in October 2007 provided Mexico \$I billion 
for the purchase of advanced military and surveillance equipment. ${ }^{87}$ Fusion centers have been established at different spots in the country to centralize and synthesize the analysis of crime data. ${ }^{88}$ And a trio of innovative programs were set up during the Calderón sexenio (six-year term) with the intention of monitoring people and the things commonly used in the commission of crime: the National Registry of Mobile Telephone Users (RENAUT), a governmental database of cell phone lines and their subscribers, which would aid authorities in responding to kidnappings and extortion calls; the Citizen Identity Card (CEDI), a national identity card featuring biometric data such as fingerprints and iris scans, which would increase people's security from identity theft and fraud; and the Public Registry of Vehicles (REPUVE), a centralized federal registry of every vehicle in the country, along with attached RFID tags, which would combat car thefts, kidnappings, and drug trafficking.

The embrace of surveillance technologies to fight organized crime in Mexico invites a variety of questions. Have the surveillance technologies reduced insecurity? How have the technologies affected the government's ability to combat organized crime? How do people react to them? And what does the use of surveillance technologies tell us about the types of government we can expect in the future, both in Mexico and beyond?

\section{I.4 SURVEILLANCE TECHNOLOGIES IN MEXICO'S WAR ON CRIME: A METHODOLOGICAL OVERVIEW}

The pages that follow are an effort to answer these questions using a case-study methodology_studying particular instances of a phenomenon (in this case, governments' use of surveillance technologies against insecurity) in order to understand it in depth and in context. ${ }^{89}$ I examine the three surveillance programs mentioned above: the RENAUT, CEDI, and REPUVE, with particular emphasis on the last program. I had originally planned to study the REPUVE exclusively, which appealed to my interest in cars, governance, and Latin America. Inclusion of the RENAUT and CEDI was motivated by what became a central theme for the book: the difficulties that authorities encounter in trying to implement monitoring programs. Arriving in Mexico in summer 2010 to begin preliminary research on the REPUVE, I was surprised to find, given the fanfare that had accompanied the program's launch in 2009, that few of my friends and acquaintances in Mexico City had heard of it. 
Concerned that a fledgling program might fail to generate an adequate amount of data, I elected to research the other two programs as well.

To examine the programs, I relied on a triangulation of qualitative and quantitative methods and collected data over a four-year period, from 2010 to 2013 . The first source of data were newspaper reports and government documents on the three programs that I collected primarily through the Google Alerts service for gathering Web content. The majority of this material came from national newspapers in Mexico, such as El Universal, Milenio, and La Jornada, and local papers from the areas where the programs were being implemented. I maintained a separate electronic file for each program. Altogether, these files comprised over three hundred thousand words. I used content analysis to identify key facts and themes.

A second source of data were observations I completed at two REPUVE registration sites in the states of Zacatecas and Sonora. During these field visits, I spent time with the staff responsible for inspecting vehicles and registering vehicular data in the REPUVE database and focused my attention on how the technologies worked in practice. These visits also enabled me to converse with staff and local program administrators to learn their opinions of the program and the successes and challenges they experienced. I also interviewed drivers who were registering their vehicles in order to understand their impressions of the REPUVE. These interviews usually lasted between five and fifteen minutes, and I interviewed thirty-five drivers in all.

I also interviewed eight national-level REPUVE administrators working at the offices of the Executive Secretariat of the National System of Public Security (SESNSP) in Mexico City. During separate visits to the SESNSP, I was able to speak with officials working in each of the REPUVE's four directorates: the State and Federal Operations Implementation Directorate charged with supervising the program's adoption by states (entidades federativas) and federal agencies (autoridades federales); the Relations with Obligated Subjects Directorate responsible for ensuring the compliance of private-sector businesses (sujetos obligados); the Procedures and Citizenry Directorate responsible for managing the public's contact with the program; and the Oversight and Verification Directorate charged with technical aspects of vehicle inspections. I usually conducted these interviews in small groups, organized by directorate, which facilitated scheduling.

The REPUVE directors at the SESNSP also arranged meetings for me with representatives from two automobile companies, which I refer 
to as Sucaro and the Veloz Motor Company (VMC). ' I met with the Sucaro representatives at the SESNSP's Mexico City offices and with VMC staffers at the company's car plant. I also toured the VMC facility to better understand its process for complying with the REPUVE.

In Mexico City, I also visited ten auto dealerships to collect their impressions of the REPUVE program. These interviews, like the interviews with drivers, lasted between five and fifteen minutes. In addition, I attended a security technology trade show to gather observations and discuss the three programs with retailers. I followed this with an interview with a representative from a company that had unsuccessfully competed for the contract to supply RFID tags to the REPUVE. I conducted all interviews in Spanish, with the exception of that with the RFID company representative. Two undergraduate research assistants later transcribed the audio files, and I analyzed the transcripts by hand to identify key themes.

Finally, to better understand the public's reaction to the three programs, I created a sixty-item survey on the programs and insecurity in Mexico more generally. The survey provided respondents a description of each program culled from newspaper accounts and asked their opinions of them. Friends in Mexico helped me refine the instrument to improve readability. To gather data, I used snowball sampling with acquaintances in Mexico via Qualtrics and employed a data-collection company, Indagaciones y Soluciones Avanzadas, to distribute the survey in two sites that I could not access on my own-a working-class neighborhood in Mexico City and a rural community in Zacatecas. This purposive availability sample consisted of ninety-eight people. The data was coded into a SPSS file with the assistance of my research assistants.

These methods are not without their problems. An initial concern is the selection of Mexico as a site for studying surveillance technologies in the first place. Readers, especially Mexico scholars, might object that the country's unique historical and political development-for instance, the Spanish conquest and the lingering inequalities between European, mestizo, and indigenous populations; the Mexican Revolution's legacy of dislocating the country's elite and remaking the armed forces; and

b. Throughout, I use pseudonyms for the individuals and car companies I interviewed or observed. Providing research participants anonymity facilitated their participation and protected them from any possible reprisals their critical assessments of the programs or the government might risk. For individuals and companies mentioned in publicly available news reports, I used their true names. 
the revolutionary state's corporatist framework and land redistribution program-limit its value as a case from which larger trends concerning surveillance technologies can be generalized. But a similar argument could be made about nearly any country - the peculiar longevity of the US Constitution, the history of slavery and racial inequality, the political and cultural legacy of the Civil War, the experience of westward expansion, and the unique geopolitical consequences of serving as a superpower have not prevented scholars from conducting research in the United States that informs social science more generally. What is more, as noted earlier, the insecurity and organized crime currently afflicting Mexico and the political strategies that authorities use to address it are very much regional and global trends. ${ }^{90}$ Thus, rather than limiting ourselves from making larger statements on the basis of casestudy methodology, I find it more useful to acknowledge the specificities of the settings studied, reflecting on how they affect the generalizability of a study's findings.

Beyond this, each of the methods utilized in this work possesses its own limitations. Media coverage is not the most reliable data source, given the political and financial concerns that inform coverage. ${ }^{c 91,3}$ While I acknowledge this, my research relies on mainstream media sources that are generally viewed as reputable in Mexico, such as the newspapers $E l$ Universal, Milenio, and the current events weekly Proceso. In terms of both the observations and interviews, a main concern is the quantity of data. I focus on the REPUVE rather than the RENAUT and CEDI; my observations are limited to two field sites; and my interviews are with a select group of public administrators, workers, businesses, and users. I have little doubt that extending the interviews and observations to the RENAUT and CEDI would have yielded important insights on these programs and that conducting observations of the REPUVE in additional sites and interviews with more officials, businesses (such as insurance companies), and users would have produced distinct data. Nevertheless, the information collected does provide a robust view of the three programs, especially the challenges faced by the REPUVE. And the interviews produced common themes that, if not capturing the whole story of the REPUVE, represent key points for understanding its history.

c. To underscore this point for research on Mexico, in March 20I I, representatives from various news outlets signed an accord with the federal government agreeing not to circulate stories that would threaten state operations against crime groups or cast the government in a negative light. 
Finally, the survey instrument itself is limited because I did not distribute it to a random sample of Mexicans, it included a low number of respondents, and it lacked sophisticated measures of question reliability prior to circulation. Thus, the survey is not representative of Mexicans' thinking about the three programs and insecurity. But the survey results still provide rare insight into the thoughts of the public on the use of surveillance technologies in Mexico's War on Crime.

In sum, the methods used in this study possess not insignificant limitations that restrict the quantity and quality of the information examined. However, the variety of data examined here is a strength. And it proves adequate for discerning the histories of the three monitoring programs launched by the Calderón administration and reflecting on their significance for understanding the impact of surveillance technologies on contemporary governance more generally.

\section{5 MAKING THINGS STICK: THE ARGUMENT IN BRIEF}

This book's main argument is twofold. First, while surveillance technologies adopted in the name of security are generally understood as tools used by state authorities to monitor individuals, they are also used to monitor the things (automobiles, telephones, etc.) thought to underlie the commission of crime. It is not simply the individual driver, phone user, or name bearer that the REPUVE, RENAUT, and CEDI target, but the broader activities of automobility, mobile telephony, and personal identification in general. By adhering RFID tags to vehicles, having people register their phones, and creating identity cards based on biometric data, the state looks to gain purchase on the material basis of everyday life.

Monitoring mobility, communication, and identification are not new concerns for the state. Rather, they are inherent to "seeing like a state, " strategies of governance that have been central to the formation of the state in Mexico over the course of its history. The Spaniards' military conquest of the Mixteca kingdom ruling the Valley of Mexico, the imposition of the Spanish language and naming practices on indigenous populations, the registration of individual citizens for the purposes of democratic elections following independence, the construction and securitization of roadways during colonial times, and the construction and securitization of railways during early modern times, among other examples, all represented efforts by authorities to control 
mobility, communication, and/or identification in order to realize social control. And such efforts were significant to the evolution of the state in Mexico.

But the creation of the REPUVE, RENAUT, and CEDI in the current day speaks to a crisis of governance-born of a society that has become increasingly difficult to administer over the past thirty years and a state apparatus that has become increasingly unable to govern society-that surveillance technologies are intended to address. In Mexico, lawenforcement officers and agencies are often corrupt; the data that the state generates on people and things are often inaccurate; and multiple agencies at local, state, and federal levels of government are often dedicated to the same task. Such obstacles within the state make governance challenging. Programs like the the REPUVE, RENAUT, and CEDI, by routing the information that RFID tags, mobile devices, and electronic identity cards produce through centralized databases, would enable the federal government to reduce its reliance on officers and agencies at the state and local levels that are seen to have become ineffective in the task of governance. ${ }^{93}$ These programs would reform the state.

The surveillance technologies employed in the REPUVE, RENAUT, and CEDI possess, then, a dual purpose. They are intended to increase the federal government's grip over the mundane objects of everyday life, and they are intended to consolidate governmental authority over the administration of these things. I refer to this novel approach to governing as probesion, a neologism formed from the Latin root, haereo, which means "to hang or hold fast, to hang, stick, cleave, cling, adhere, be fixed, sit fast, remain close." It is the root of the words "adhesion" and "cohesion," "adherence" and "coherence." And I use it in an allusive attempt to describe the efforts of authorities to make the materiality of social life more "adhesive" and the diverse organizations of government more "cohesive" to the state. To explain the title of the book, the surveillance technologies studied in this work are designed to "make things stick."

That is the first part of the argument. The second part is that the vision of state authorities in Mexico to "make things stick" has largely failed. Today, none of the three programs operates in the manner state planners had intended. To most Mexicans, this does not come as a surprise. While I was conducting research, many people I spoke withwhether they supported the programs or not-had a hunch that these programs would fail, like so many past efforts by the state. 
But if failure is not surprising, one goal of this book is to try to bring the reasons for it to light. They are multiple. Ordinary people either refuse to register for programs or register using false information. Businesses push back against regulations that require them to add new procedures for complying with the law. Technologies fail to work in the manner expected. Resources are insufficient to successfully implement the programs on the scale desired. Political intrigue affects elected officials' willingness to follow the federal government's lead on security programs. States neglect to implement programs as they hold out for increased resources from the federal government. Thus, multiple points of resistance operate to weaken the federal government's efforts to remake the state through prohesion.

But weakness cannot be mistaken for absence. While the automobile registry, mobile phone registry, and personal identity card launched during the Calderón administration do not work in the way they were imagined, the programs, the ideas that inspired them, and the technologies that embody them operate in modified form. That they operate at all owes in good measure to the political acumen of program administrators to respond to the resistance the programs encounter and find points of connection with the individuals, groups, businesses, politicians, and things that oppose them. Programs are added onto existing state infrastructures in order to reduce costs, or they are reframed as intended for vulnerable populations in order to increase the programs' legitimacy, or they are eliminated altogether to allow the state to pursue alternative methods of managing mobility, communication, and identification. Such improvisational practices, which I refer to as statecraft, lend state formation an emergent quality, unknowable in advance but taking shape through practices and patterns of rule inherited from the past. If the fickle nature of statecraft proves discouraging for those in search of definite answers to how surveillance technologies will affect relations between governors and the governed in Mexico, it also ensures that a space for meaningful political action will continue to exist in our technological future.

\section{6 CONTRIBUTIONS: SURVEILLANCE, STATE}

FORMATION, SOCIAL THEORY, AND LATIN AMERICA

In this work, the academic field I am in closest dialogue with is surveillance studies, and here, the points of connection are multiple. First, this 
work provides a more robust understanding of surveillance technologies by emphasizing dimensions of their operation beyond sight and vision. Our thinking on surveillance has been dominated by sight as a human sense. If cover art on leading social science books about surveillance is any measure, surveillance brings to mind CCTV cameras, computer monitors, magnifying glasses, X-ray images, and other devices designed to promote visibility. This emphasis prevails in the way surveillance gets discussed as well, as evidenced by such terms as "SuperVision," "stretched screens," nology communicate the idea that surveillance technologies increase the ability of authorities to watch over their subjects.

Besides being reasonable, this stress on visibility is important for understanding the shifting nature of power brought forth by surveillance technologies. CCTV cameras have become ubiquitous in the contemporary world, with Great Britain notoriously leading the charge with some six million devices for a population of sixty million people. ${ }^{97}$ Cameras in mobile devices have increased imagery in the world, presenting new dilemmas for concerned parents of teens who share explicit images of themselves as well as new opportunities for "sousveillance," or the watching of authorities by those below them. ${ }^{98}$

But there are also reasons to be skeptical about the power of sight and our emphasis on it. Jean Baudrillard introduced the concepts of "simulacra" and "simulation" to comment critically on the changing relationship between image and reality in society. Today, we find ourselves moving "from a capitalist-productivist society to neo-capitalist cybernetic order that aims now at total control" through "the minute duplication of the real, preferably on the basis of another reproductive medium—advertising, photo, etc." ${ }^{99}$ William Bogard has integrated these ideas into his work on surveillance, arguing that simulation "functions in ways that are totally contradictory to surveillance-not as a method of exposure or unconcealing, but the fabrication of completely original scenes, pure fictions that bear absolutely no relation to 'reality' at all, not even as a signified absence. ${ }^{\text {, }}$

Beyond the reality of digital imagery, a range of information technologies such as RFID tags, biometric cards, mobile devices, personal computers, and the networks that link these devices have transformed the nature of surveillance. Sensitivity to how the technical means of surveillance have transformed the nature of monitoring is captured well in the disparate definitions of surveillance offered by prominent scholars 
in the field. ${ }^{\mathrm{d}}$ Common to each is surveillance as the processing and analysis of data, or "dataveillance." ${ }^{\text {ior }}$

With this broader field of surveillance studies in mind, the RENAUT, the CEDI, and the REPUVE in Mexico serve as detailed case studies of the technical and administrative operations required to erect a "surveillant assemblage" that collects data on telecommunications, personal identification, and automobility. These cases support the development of what can be thought of as a "material perspective" of surveillance technologies. ${ }^{\text {102 }}$ To create an electronic identity card based on biometric data, the human body is probed in different ways. Fingers are touched and recorded, irises are scanned and logged, and that data is encoded into barcodes and other formats stored in the card as well as government databases. To create an automobile registry, the body of the car is inspected and touched in order to record multiple instances of a vehicle identification number, and that data is then inscribed into government databases and RFID tags applied directly to vehicles' windshields. With these technologies, authorities seize directly on the body or materiality of the agencies of communications, identification, and mobility. This emphasis on touch and adhesion is why it is meaningful to speak of prohesion. If surveillance is understood as "watching over people" for the sake of affecting their behavior, the histories of surveillance technologies in Mexico reveal an operation in which authorities through technological means attempt to get and keep a hold upon the things that energize social life. Taken a step further, if the eighteenth and nineteenth centuries witnessed a "slackening of the hold of the body" ${ }^{\mathrm{I} O 3}$ by authorities, who turned their focus to the soul, the contemporary world finds authorities renewing their interest in seizing upon the body. ${ }^{\text {Io }}$

d. Gary T. Marx defines this new surveillance as "scrutiny through the use of technical means to extract or create personal or group data, whether from individuals or contexts," carefully choosing "the verb 'scrutinize' rather than 'observe' [to] call attention to the fact that contemporary forms often go beyond the visual image to involve sound, smell, motion, numbers, and words" (Marx, "Surveillance and Society," 2). David Lyon defines the new surveillance as "any collection or processing of personal data, whether identifiable or not, for the purposes of influencing or managing those whose data have been garnered" (Lyon, Surveillance Society, 2). Torin Monahan, for his part, studies "surveillance systems ... that afford control of people through the identification, tracking, monitoring, or analysis of individuals, data, or systems" (Monahan, Surveillance in the Time of Insecurity, 8). And Kevin Haggerty and Richard Ericson describe a "surveillant assemblage" that "operates by abstracting human bodies from their territorial settings, and separating them into a series of discrete flows.... These flows are then reassembled in different locations as discrete and virtual 'data doubles'" (Haggerty and Ericson, "Surveillant Assemblage," 605). 
A second point of engagement with surveillance studies concerns the state. Although policing, national security, and border control-activities where state authorities exercise legitimate force over populationsare common topics within surveillance studies, the state often only lies in the background. On the one hand, reflecting their debt to Michel Foucault and poststructuralist perspectives more generally, many studies view the adoption of surveillance technologies as indications of modes of thinking and acting-referred to variably as "governmentality," ${ }^{105}$ "risk," the backs of authorities. On the other hand, some studies make reference to the state through the legislation (USA Patriot Act, US "Real ID" Act, Enhanced Border Security and Visa Entry Reform Act, etc.) and institutions (Department of Homeland Security, Transportation Security Administration, Federal Bureau of Investigation, etc.) that authorize and employ the surveillance technologies in policing and national security work.

These approaches are not without their strengths. The governmentality perspective identifies operations of power beyond particular institutional contexts and in seemingly benevolent actions undertaken by state authorities. And the legislation and institutions utilizing surveillance technologies are undoubtedly a central part of the story. I use these perspectives to describe the REPUVE, RENAUT, and CEDI in the following chapters.

However, these approaches also have their limitations. As other works have shown and the latter chapters of this book illustrate, what surveillance technologies do in practice vary from what they were designed to do. ${ }^{\text {I08 }}$ And these divergences are very much tied to the structure and organization of the state and its relationship to society over time. State officials and federal agencies may have interests separate from national administrators charged with implementing monitoring programs. Inadequate resources can affect which elements of a program get implemented. And prior administrations' efforts to implement monitoring programs can make people mistrust current administrations' endeavors. By being sensitive to the complexity and dynamism of state forms and their relationship to society over time, this work looks to account for the role of the state in the outcomes of surveillance technologies.

With the previous point in mind, a third contribution of this work is to counter the dystopian normative stance of much of the surveillance studies literature. Often, scholars in the field hold the view that 
surveillance technologies will provide state authorities, and the private companies that work with them, increased control over people and will heighten stratification between different groups in society. In highlighting the struggles experienced by the RENAUT, REPUVE, and CEDI, this work challenges such assumptions. The federal government in Mexico consistently comes across as weak in this work, as companies oppose surveillance measures for the costs they add and people mobilize to block measures. The point is not that scholars should be cheerier about surveillance technologies. Rather, it is that the role of surveillance technologies in mediating our relationship with state authorities can only take shape through the messy operations of statecraft, making both negative and positive outcomes possible. As Gary T. Marx notes, "Perhaps then a nuanced perhapsicon model better captures our situation than either a panopticon or an utopicon model." ${ }^{\text {I09 }}$

Beyond surveillance studies, this work also speaks to research on state formation. Recent years have seen a number of excellent works inspired by science and technologies studies (STS) that illuminate how technoscience is implicated in state formation. The application of statistics, cartography, sanitary engineering, and the like in colonial Ireland transformed the island into a laboratory of English science and government and laid the foundation for the emergence of modern government. ${ }^{\text {IO }}$ Scientists and engineers, through agricultural, environmental, and military planning that helped exploit Saudi Arabia's vital nonpetroleum natural resources, gave shape to the basic institutions of that country's political system. ${ }^{\text {III }}$ The Baku-Tbilisi-Ceyhan pipeline through Azerbaijan, Georgia, and Turkey is central to the construction of geopolitical order in the region and occasions new relations between nature, corporations, and publics. ${ }^{\text {II2 }}$ And Stafford Beer's failure to cybernetize the socialist economy of Chile in the early I970s was central to the inability of the Salvador Allende administration to build a lasting socialist state as an alternative to the international capitalist order. ${ }^{\mathrm{II} 3}$ Each in its own way, these examples illustrate that scientific knowledge and technological artifacts, in addition to coercion and capital, ${ }^{\mathrm{II} 4}$ are intimately involved in the "co-production" ${ }^{\mathrm{IIS}}$ of the state and social order.

This investigation into authorities' efforts to manage mobility, communication, and personal identification over the course of Mexican history contributes to this trend. The colonial government's attempts to secure roadways buttressing the extraction of silver and other natural resources gave birth to the Tribuna de la Acordada, a policing organization charged with protecting roadways from bandits. Efforts to 
implement voting procedures in the country following independence from Spain led to the creation of both mailed ballots-de facto identity cards for individual voters-and governmental agencies to administer them. And interest in bolstering support for the postrevolutionary state in Mexico led authorities to construct schools throughout rural Mexico that would combat the hold of the Catholic Church on the Mexican worldview. Material artifacts, in brief, have served to co-produce the Mexican state.

But this study also provides deeper insight into the processes of state formation. Older forms of state organization and practice that first emerged to manage social activities such as interpersonal communication-a state telephone monopoly, for instance-can lose their grip on society as new technologies (e.g., the mobile phone) transform the practice of communication. This leads state authorities to consider new tactics-the surveillance technologies of the RENAUT, the CEDI, and the REPUVE-to regain their grip on the social order. But older forms of government do not simply wither away as their utility diminishes. Aging institutions, bureaucracies, offices, actors, and patterns of behavior present a counterweight to new ways of governing. Thus, state forms and practices must continually be negotiated by administrators through the practice of statecraft, which gives the state a dynamic, indeterminate quality. The state is continually being remade, built on infrastructures and patterns of interaction inherited from the past.

This emphasis on the evolutionary indeterminacy of state forms contributes to theorizing on social order more generally. In recent years, the social sciences have shown heightened interest in incorporating what has been referred to as posthumanist thought from STS as a way of moving beyond the discursive focus of poststructuralism and social constructivism. Posthumanist thinking, or "assemblage theory," ${ }^{\text {I16 }}$ emphasizes the materiality of the social world, the distribution of agency between human and nonhuman actors, and the emergent nature of social order. ${ }^{\text {II7 }}$

This theoretical current informs the present work in multiple ways. For instance, the primary object of the surveillance programs studied here are the material things (automobiles, mobile devices, and body) through which distributions of agency (mobility, communication, and identification) circulate in society. Prohesion is designed to make these things stick. The durability of social assemblages is vital as well, as past forms of governance can resist the efforts of government leaders to adopt new ways of administering the world. And, as noted above, the 
form of the state emerges in time through the statecraft of administrators and bureaucrats in countering the resistance to their efforts.

But this work also cautions against overemphasizing the nonhuman in the emergence of social order. Studies adopting the language of STS and assemblage theory often approach social formations as self-organizing systems, a view perhaps nourished by the fact that the natural world has often served as a muse in key texts in the field. ${ }^{118}$ But if agency in the world is distributed between humans and nonhumans, this invariably means that cultural beliefs, skills, and practices are still central to social outcomes. In the case of the REPUVE, RENAUT, and CEDI, it is the program directors and administrators working behind the scenes who help determine which pieces of old programs and infrastructures can be repurposed for integration with new ones, which businesses can be persuaded to be early adopters of new programs, which state actors can be negotiated with and convinced to implement them, which technical problems can be fixed and which cannot, and so forth. The word "statecraft," like "bricolage" "119 and "metis," to highlight this practical aspect of social order. And these examples encourage us to remain attentive to the potential of human action to influence and remake the world.

Finally, this work is also in dialogue with research on politics and insecurity in Latin America. As noted earlier, following a period of democratization in the I980s and I990s, the liberalization of the region's economies, the accompanying retreat and contraction of the state, and the integration with the global economic order have provided fertile ground for the intensification of illicit drug and human trafficking by organized crime syndicates. ${ }^{\mathrm{III}}$ These criminal organizations have penetrated the state to become integrated elements of the social order. ${ }^{\text {I22 }}$ Security has as a result becomes a key policy focus for governments in the region, defined by an increasing militarization of police forces, the adoption of legal reforms that expand the coercive power of the state at the expense of civil liberties and protections, and regional collaborations with neighboring governments to coordinate crime-fighting efforts. ${ }^{\text {I23 }}$

The present work adds to that literature by emphasizing the role of technology in both the creation and response to insecurity. The growing use of mobile devices, automobiles, and online identities by large numbers of people in Mexico presents new challenges to state authorities looking to combat crime amid institutional corruption and in a neoliberal era of reduced budgets. And surveillance technologies such as RFID 
tags, GPS devices, biometrics, and computer networks are embraced as a way to reshape the state to meet the security challenges of the day. Thus, to better understand security measures in contemporary Latin America, we must squarely focus attention on the technologies and material things of modern life and governance.

In addition, to the extent that we scholars who study Latin America are invested in social outcomes in the region, this work provides some measure of hope. While some studies exhibit a measure of skepticism or uneasiness about Latin American governments' adoption of surveillance technologies, ${ }^{\mathrm{I} 24}$ stances that simulate the dystopian trends of surveillance scholarship more generally, this work illustrates how surveillance technologies can bring about a remaking of the state that requires the participation of ordinary citizens. In this sense, surveillance technologies can serve as an opportunity for people to engage with the state and, in the process, strengthen democracy and the rule of law.

\section{I.7 AN OVERVIEW OF THINGS TO COME}

Over the next five chapters, I develop these ideas in greater depth. Chapter 2, "Taming the Tiger," begins with a description of the Registry of Mobile Telephone Users, Citizen Identity Card, and Public Registry of Vehicles and then considers them in light of larger historical trends in Mexican history. It argues that while the RENAUT, the CEDI, and the REPUVE resemble programs described by surveillance scholars elsewhere, they are most noteworthy for their focus on the materiality of communication, identification, and mobility. Authorities' efforts to administer these activities are not new; rather they date back to the Spanish conquest and have over the course of Mexican history "co-produced" the state. The launching of the RENAUT, CEDI, and REPUVE in Mexico today, however, speaks to a crisis of governance that the democratization of the country's political system, liberalization of its economy, and transnationalization of its culture-all aspects of globalization-have brought about.

Chapter 3, "Prohesion," delves into the operation of surveillance technologies by locating the REPUVE within the history of automotive governance in Mexico. This chapter argues that the REPUVE evidences a third historical approach to governing the insecurity of automobility. Discipline was first pursued to increase the safety of road travel by making drivers responsible. Risk management later emerged to reduce the environmental harm of automobility by monitoring car emissions. 
The third phase, which I term "prohesion," operates not by targeting the subjectivity of drivers or the invisible emissions of vehicles, but by gaining a hold of the materiality of vehicles in order to achieve "legal certainty" about automobiles. The bodies of vehicles are inspected and registered into the registry, while RFID tags are adhered to their windshields in order to provide the state a constant presence or hold on vehicles. Through prohesion, the federal government in Mexico attempts to respond to the challenges of globalization by making the material things of society and the administrative agencies of the state stickier and more cohesive.

Chapters 4 and 5, "Ni Con Goma" and "Statecraft," examine the difficulties inherent in trying to make things stick. Chapter 4 reviews the different points of resistance encountered by the REPUVE, RENAUT, and CEDI programs in Mexico. As noted above, ordinary people, corporate actors, technological artifacts, and state entities all in their own way defy the federal government's efforts to gain a grip over mobile telephony, personal identification, and automobility. Thus, resistance is inherent in prohesion and threatens state designs to control these collective activities. But more than this, opposition to the programs demonstrates the force of history in Mexico, where particular formations or "assemblages" ${ }^{125}$ of personal identification, mobility, and communication and their governance forged during earlier periods persist in the face of official efforts to reshape them. Taking these lessons to heart, the chapter seeks to broaden our conception of resistance in sociopolitical contexts to explain the weakness of surveillance technologies as tools of governance.

In response to such resistance, authorities in Mexico have needed to make various alterations to the RENAUT, CEDI, and REPUVE. To reduce popular resistance, administrators tie theses initiative to existing programs and institutions that ordinary Mexicans already deem legitimate. To overcome private-sector resistance, the federal government does not penalize companies that at least show good faith in implementing the programs. To overcome state resistance, federal authorities allow local government to charge people for enrolling in the registries, seemingly in violation of the law. In brief, prohesion, or making agencies stick, requires authorities to engage in statecraft, modifying program requirements and operations on the fly. Administrators who are able to put surveillance programs into action in Mexico through statecraft alter the programs' function and meaning, giving the state an emergent quality. While such accommodations might seem to evidence the chaotic 
nature of the Mexican state, they are better considered as signs of a collaborative impulse that bode well for Mexico's democratic future.

As these summaries suggest, this work offers a different conception of surveillance technologies than that generally encountered, one that is wider in scope and hopefully better suited to comprehending the workings of governance in global society. In the Chapter 6, "Grasping Surveillance," I reflect on the theoretical lessons of this study in terms of four themes: tactility, weakness, emergence, and engagement. These are meant as conceptual counterweights to tendencies that often frame our thinking on surveillance: visibility, strength, determinism, and fatalism. While the tactility of prohesion as a security strategy provides an ominous vision of a future that surveillance technologies could usher in, these technologies' weakness provides the solace of knowing that political engagement will remain central to whatever outcomes emerge. With these lessons in mind, the work finishes by considering what courses of action subjects in the surveillance society might meaningfully take to help create more democratic futures. 